\title{
Pengembangan SmaRT FEWS UNS berbasis camera sebagai Upaya Deteksi Dini Bahaya Banjir Luapan Sungai Samin
}

\author{
Mohtar Yunianto ${ }^{1)^{*}}$, Fendi Aji Purnomo ${ }^{2)}$, Nanang Maulana ${ }^{2)}$ \\ ${ }^{1)}$ Program Studi Fisika, FMIPA UNS \\ ${ }^{2}$ Program Studi D3 Teknik Informatika, FMIPA UNS \\ E-mail: mohtaryunianto@staff.uns.ac.id
}

\begin{abstract}
ABSTRAK
Telah dilakukan pemetaan, pembuatan serta pemasangan alat deteksi dini banjir SMaRT FEWS UNS luapan Sungai Samin yang merupakan anak Sungai Bengawan Solo. Alat deteksi dini yang dipasang menggunakan arduino, catudaya menggunakan panel sel surya dan distribusi data menggunakan camera dimana gambar hasil pengambilan data dikirim dan ditampilkan dalam aplikasi berbasis web yang secara online dan realtime serta dapat dimonitor melalui http://banjir.mitigasi.com/simonair
\end{abstract}

Kata kunci : SMaRT FEWS UNS, Banjir, deteksi banjir, camera

\section{PENDAHULUAN}

Badan Nasional Penanggulangan Bencana (BNPB) mencatat selama tahun 2017 telah terjadi 654 bencana di seluruh Indonesia. Dampak yang ditimbulkan 61 jiwa meninggal dan hilang, 174 orang luka dan 584.173 jiwa menderita dan mengungsi bencana juga telah menyebabkan 5.534 rumah rusak, dimana 1.192 rumah rusak berat, 990 rumah rusak sedang, 3.352 rumah rusak ringan, dan 87.234 rumah terendam banjir.Bencana juga menyebabkan kerusakan fasilitas publik seperti, 108 unit sekolah, 85 unit fasilitas peribadatan dan 12 unit fasilitas kesehatan rusak. Banjir terjadi di 25 provinsi dan 121 kabupaten/kota, sedangkan longsor terjadi di 13 provinsi dan 69 kabupaten/kota ( Lazuardi, 2017). Banjir merupakan aliran air sungai yang tingginya melebihi muka air normal sehingga melimpas dari palung sungai menyebabkan adanya genangan pada lahan rendah disisi sungai. Aliran air limpasan tersebut yang semakin meninggi, mengalir dan melimpasi muka tanah yang biasanya tidak dilewati aliran air (Bakornas PBP, 2002). Bencana banjir dapat disebabkan oleh kejadian alam, kejadian alam meliputi curah hujan yang tinggi, kapasitas alur sungai yang tidak mencukupi, aliran anak sungai yang tertahan oleh aliran induk sungainya, terjadinya akumulasi debit puncak sungai induk dan anak sungai di pertemuan sungai pada waktu yang sama (Eko, 2013). Daerah Sukoharjo yang terletak di selatan Kota Surakarta merupkana daerah yang langganan benana banjir, karena dilewati oleh Sungai Bengawan Solo serta anak Sungai yaitu Sungai Samin. Sungai Samin membentang dari Tawangmangu, Matesih menuju Karanganyar hingga Kabupaten Sukoharjo dan berakhir di Sungai Bengawan Solo.

Kesiapsiagaan masyarakat dalam menghadapi bencana banjir merupakan satu kesatuan dari setiap parameter pengetahuan masyarakat mengenai banjir, sistem perilaku masyarakat komunal, kelembagaan formal dan informal (petugas dinas, badan yang bertanggung jawab), peraturan formal/informal, peralatan umum atau infrastruktur, dan simulasi individu dan kelompok masyarakat (Dwi, 2014). Pembuatan Alat Deteksi Dini menjadi salah satu solusi dalam membantu masyarakat untuk menghadapi bencana banjir, masyarakat dapat mengetahui tinggi muka air sungai secara cepat dan akurat sehingga dapat dengan segera melakukan uoaya untuk penyelamatan dari bahaya banjir. 


\section{METODE}

Pemetaan dan pembuatan serta pemasangan alat deteksi dini banjir sungai Samin dilaksanakan di jembatan Glondongan yang berada di antara Desa Wonorejo dan Desa Mranggen Kecamatan Polokarto, seperti pada Gambar 1, alat dipasang pada koordinat $07^{\circ}$ 37'30' S $110^{\circ} 53$ ' 37' E. Alasan penempatan di titik tersebut adalah kemudahan akses untuk menempatkan alat serta mudah dalam pemeliharaan dan aman dari tindakan pencurian.

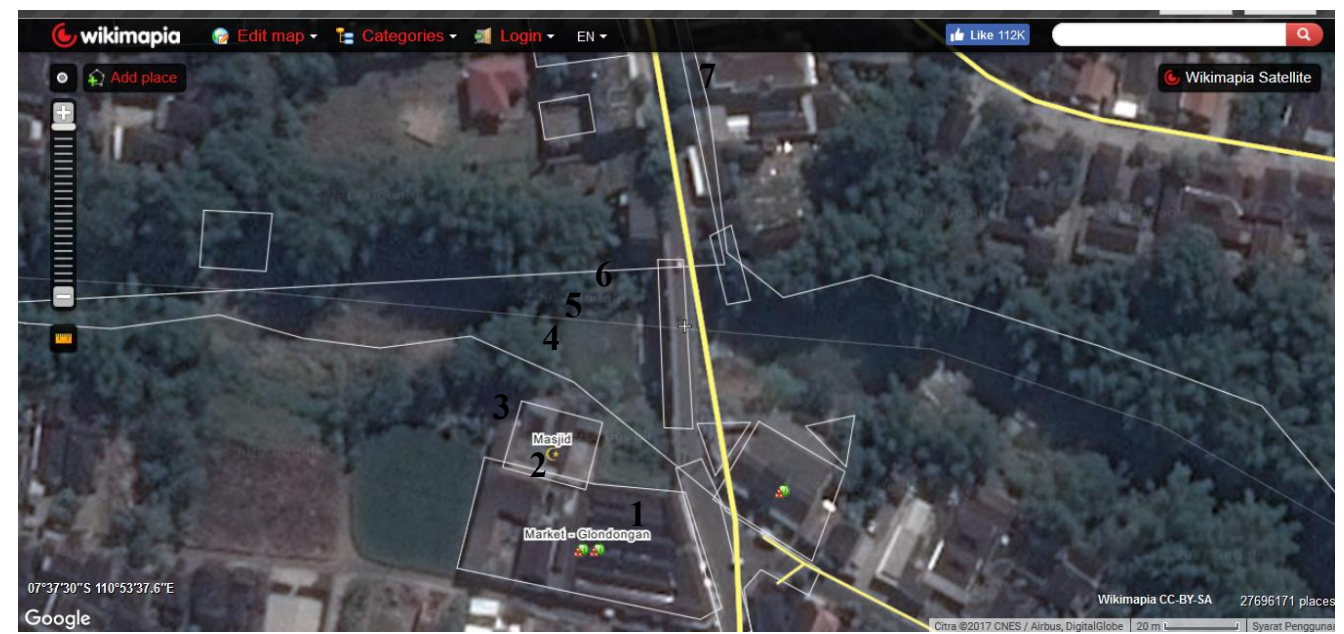

Gambar 1. Titik hasil pemetaan untuk pemasangan alat EWS

Sebelum dilakukan pemasangan alat EWS pada titik tersebut terlebih dahulu dilakukan perancangan, pembuatan serta pengujian dari alat deteksi banjir, dengan skematik rancangan sebagai berikut :

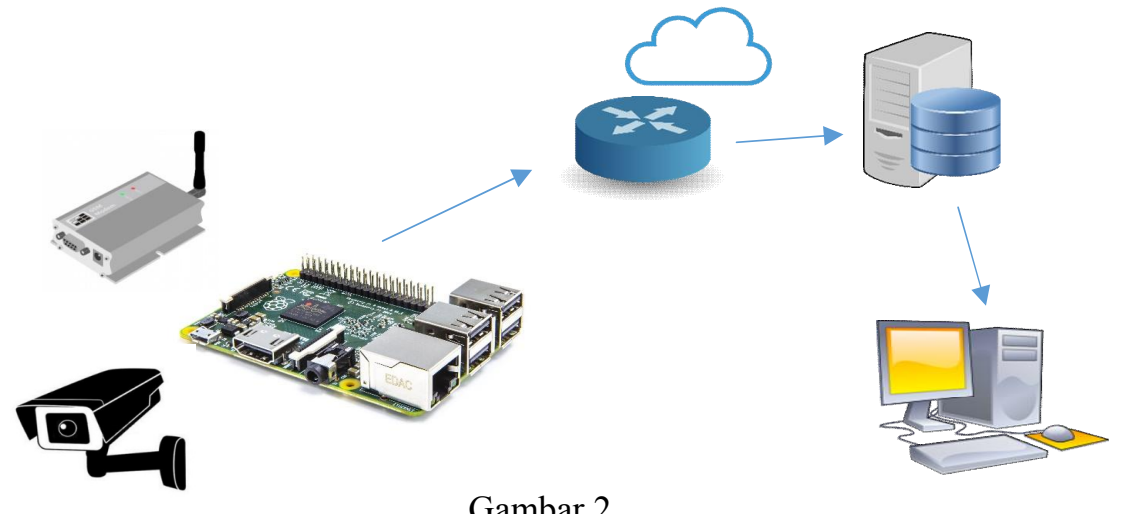

Gambar 2.

Skema pengembangan SMaRT FEWS berbasis camera

Pada gambar 2, Mini komputer (raspberry pi) merekam gambar dalam format .jpg melalui kamera yang terinstal kemudian melalui modem internet gambar akan dikirimkan ke server lengkap dengan waktu kejadian gambar direkam. Server menampilkan gambar kondisi level air kepada client melalui web. Histori gambar disimpan dalam database sehingga kondisi kenaikan level di waktu sebelumnya dapat dilihat ulang. Sebagai catu daya untuk kelistrikan menggunakan aki yang disupport oleh sel surya. 
Adapun urutan pelaksanaan dalam kegiatan penelitian yang telah dilakukan adalah sebagai berikut :

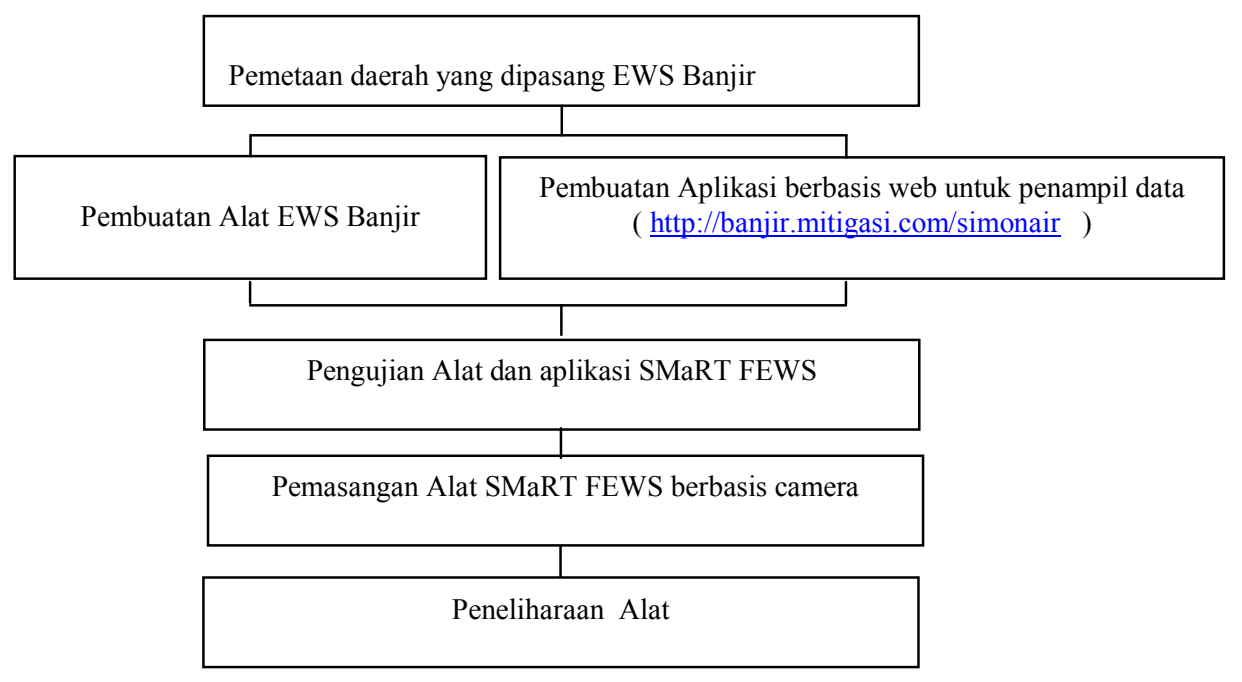

Gambar 3. Urutan pelaksanaan kegiatan

\section{HASIL DAN PEMBAHASAN}

Telah dihasilkan alat deteksi banjir berbasis camera dari hasil penelian serta telah dilakukan pemetaan untuk penempatan tersebut. Alat yang telah dibuat berbasis sensor camera serta sms dimana data terkirim ke server dan diteruskan ke client melalui web yang berisi informasi ketinggian serta gambar, prose pengiriman informasi tersebut sebagai mana diilustrasikan pada Gambar 4 berikut

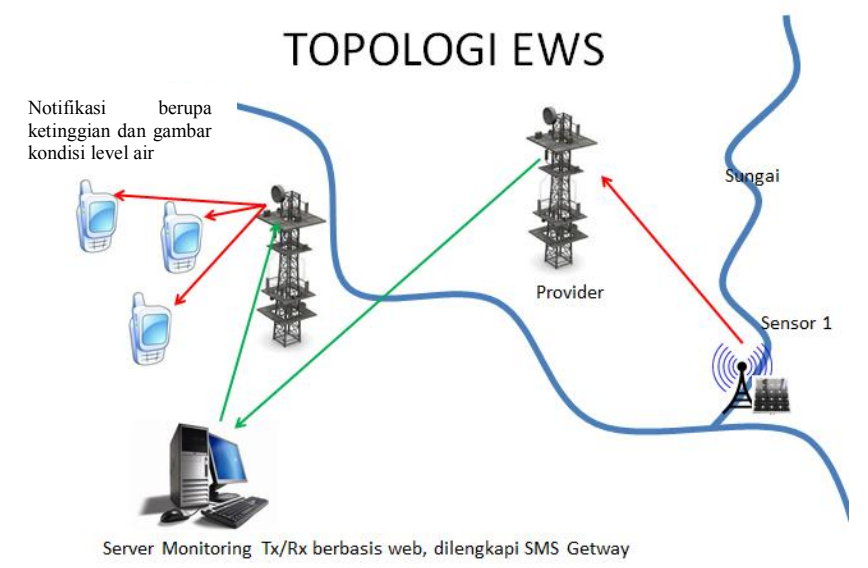

Gambar 4. Illlustrasi topologi EWS proses pengiriman data berupa informasi ketinggian dan gambar kondisi level air

Alat deteksi dini banjir telah dibuat seperti ditunjukkan pada Gambar 5, untuk proses pemasangan di lokasi yang telah ditentukan diperlukan adanya tiang penyangga, pemasangan alat tersebut yang terdiri dari box EWS, sel surya serta di letakkan pada tiang pancang berada pada daerah pingir sungai yang dekat dengan jembatan, dimana daerah tersebut tidak terkena imbas naiknya sungai samin, kemudian camera di tempatkan di daerah yang dapat mengambil gambar secara detail tanpa terhalang, adapun pemasangnnya seperti pada Gambar 6 . 


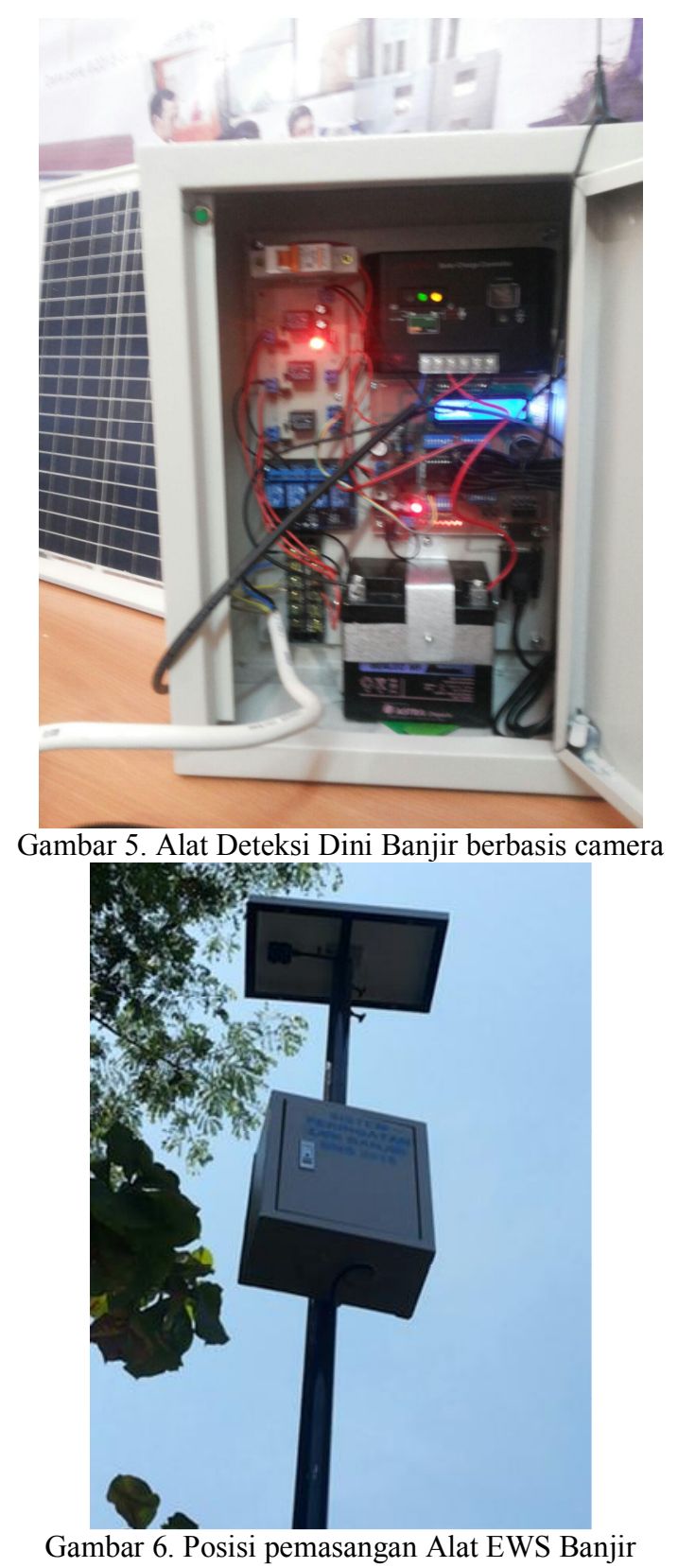

Alat yang telah terpasang tersebut kemudian di lakukan pengecekan untuk dapat memberikan informasi berupa gambar secara realtime ke server dan dapat dimunculkan ke dalam suatu aplikasi berbasis web yang beralamat http://banjir.mitigasi.com/simonair/ seperti pada Gambar 7. Aplikasi tersebut juga memberikan informasi berupa grafik status ketinggian dalam bentuk map secara realtime, dalam bentuk chart serta gambar posisi ketinggain air, demikian juga status alat yang terpasang. Gambaran dari output aplikasi dapat dilihat pada gambar 7 . 


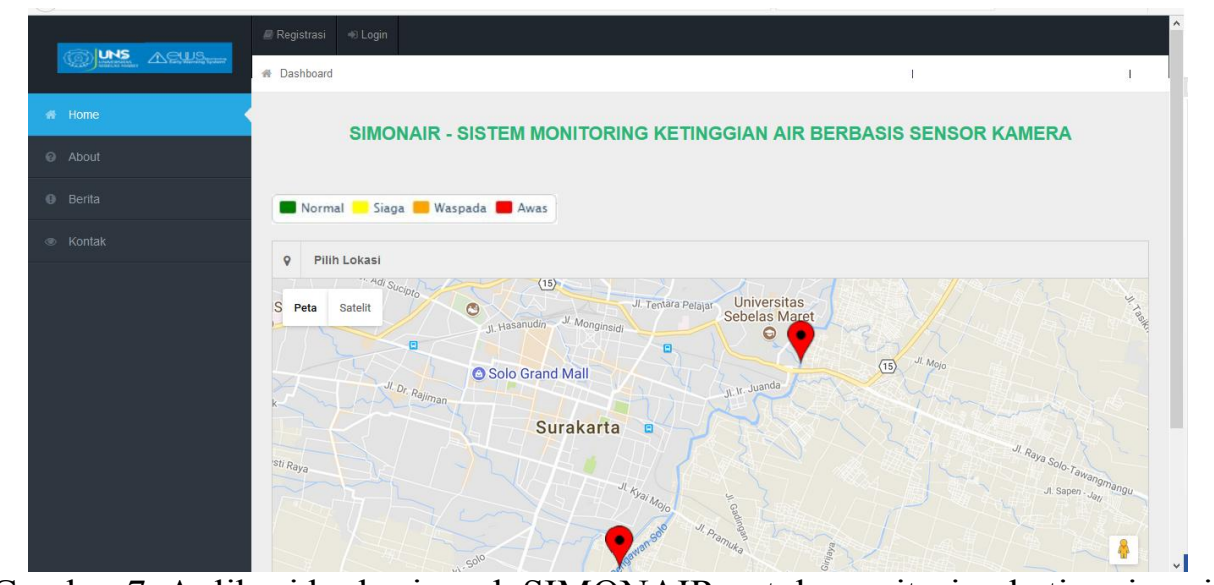

Gambar 7. Aplikasi berbasis web SIMONAIR untuk monitoring ketinggian air

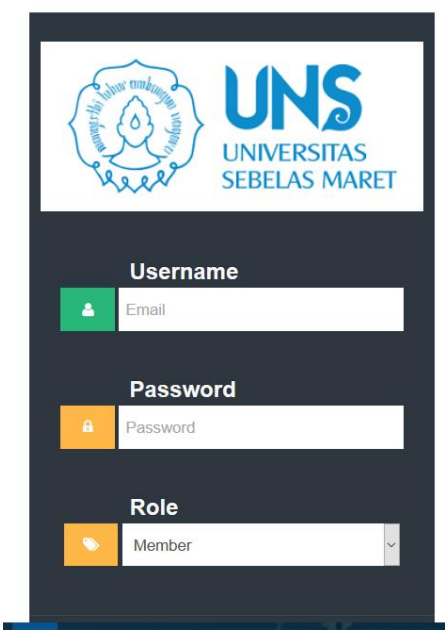

Gambar 8. Form login untuk menu lebih lengkap

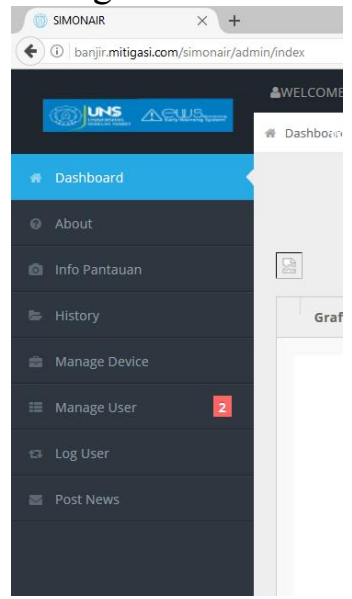

Gambar 9. Menu yang ada dalam sistem

Gambar 8 merupakan form untuk login agar dapat melakukan akses lebih detail mengenai aplikasi ini, dimana menu secara detail ditunjukkan pada gambar 9, menu diantaranya adalah menu pantauan untuk dapat memantau secara langsung, History untuk mengetahui level ketinggian air dari waktu ke waktu, manage device untuk mengatur posisi alat dan jumlah data yang terkirim tiap satuan waktu. Data berupa gambar ketinggian air dapat ditunjukkan dalam Gambar 10. 


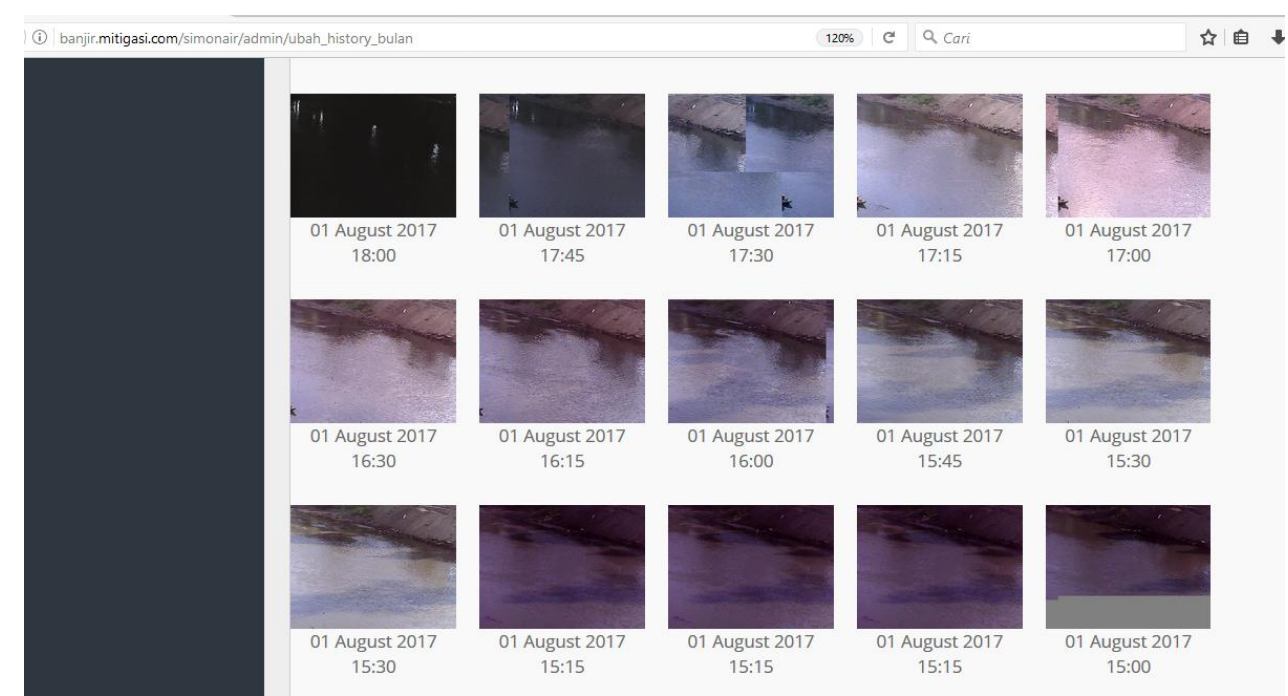

Gambar 10. Grafik monitoring level air sungai

Data-data yang sudah tersimpan dalam database di server disamping dimunculkan kedalam aplikasi berbasis web, data-data tersebut berupa gambar mengenai ketinggian air sungai dalam rentang waktu 15 menit.

\section{KESIMPULAN}

Hasil kesimpulan dari penelitian ini adalah alat deteksi dini banjir yang telah di pasang di jembatan glondongan yang berada di aliran Sungai Samin dapat memberikan informasi terkait ketinggian air sungai, dimana data yang dikirim dari alat tersebut masuk ke server kemudian di informasikan secara realtime melalui website di http://banjir.mitigasi.com/simoair, dalam website dimunculkan gambar posisi ketinggian air sungai serta grafik ketinggiannya serta grafik ketinggian dalam bentuk chart.

\section{DAFTAR PUSTAKA}

Admin, 2016, Banjir terus meluas, diakses dari http://www.suaradesa.com/berita/2016/11/30/banjir-terus-meluas pada 14 Maret 2017

Admin, 2016, Gubernur tinjau korban banjir, diakses dari http://sukoharjokab.go.id/id/kabar/gubernur-tinjau-korban-banjir pada 14 Maret 2017

Atmel, 2001, 8-bit Microcontoller with 4 K Bytes In-System Programmable-Flash AT89S51, diakses 25 Maret 2009, http://www.atmel.com/dyn/resources/prod_documents/doc2487.pdf

Azka, A, 2016, demografi desa Wonorejo, dikases dari http://wonorejokondang.blogspot.co.id/2016/04/demografi-desa-wonorejo.html pada 14 Maret 2017.

BAKORNAS PBP, 2002, Sekretariat Badan Koordinasi Nasional Penanggulanagn Bencana dan Pengangan Pengungsi, Jakarta

Boni, E, W, 2016, Banjir Bandang terjang 4 Desa di Polokarto Sukoharjo, ini kerusakannya, diakses dari http://www.solopos.com/2016/11/29/banjir-bandangterjang-4-desa-di-polokarto-sukoharjo-ini-kerusakannya-772766 Selasa, 29 November 2016 17:00 WIB pada 14 Maret 2017 
Boni,E W, 2017 Banjir Sukoharjo Banjir Kali Samin seperut orang dewasa, diak ses dari http://www.solopos.com/2017/02/02/banjir-sukoharjo-banjir-kali-samin-seperutorang-dewasa-warga-pilih-tunggu-air-surut-789591 pada 14 Maret 2017

Eko Budi Santosa, 2013, Manajemen Risiko Bencana Banjir Kali Lamong pada kawasan peri-urban Surabya-Gresik melalui pendekatan kelembagaan, Jurnal Penataan Ruang, Vol 8, No 2, Hal 48-59

Dwi Mulyani, 2014, Kesiapsiagaan Masyarakat Dalam Menghadapi Bencana Banjir Di Desa Ngombakan Kecamatan Polokarto Kabupaten Sukoharjo, Skripsi

Giancoli, D. C., 1997, Fisika Jilid 1 (Terjemah), Edisi Empat, Erlangga, Jakarta.

Glery Lazuardi, 2017, Bnpb: Terjadi 654 Bencana Alam Sepanjang 2017, Diakses Dari http://www.tribunnews.com/nasional/2017/02/27/bnpb-terjadi-654-bencana-alamsepanjang-2017 Senin, 27 Februari 2017 20:09 Wib

Suprapto, 2011, Statistik Pemodelan Bencana Banjir Indonesia (Kejadian 2002-2010), Jurnal Penanggulangan Bencana, Vol 2 Nomor 2 Hal 34-47

Undang-Undang Republik Indonesia Nomor 24 Tahun 2007 tentang Penganggulangan Bencana 